\title{
27. THE EARLY CRETACEOUS ENVIRONMENT AT DEEP SEA DRILLING PROJECT SITE 463 (MID-PACIFIC MOUNTAINS), WITH REFERENCE TO THE VOCONTIAN TROUGH (FRENCH SUBALPINE RANGES) ${ }^{1}$
}

\author{
S. Ferry, Université de Lyon, Département de Géologie et Laboratoire de Paléontologie \\ Stratigraphique et Paléoécologie Associé au CNRS, 43, Bd du 11 Novembre, 69622, Villeurbanne Cedex, France \\ and \\ A. Schaaf, Université de Strasbourg, Institut de Géologie, 1 rue Blessig, 67084 Strasbourg Cedex, France
}

\begin{abstract}
Barremian to lower Aptian interbedded pelagic and clastic limestones cored in the western Mid-Pacific Mountains (Deep Sea Drilling Project Site 463) show strong affinities with coeval deposits from a small Cretaceous basin, surrounded by "Urgonian" carbonate platforms, on the northern margin of the Tethys. We suggest that the depositional environments were nearly the same: a saddle on a structural high (Pacific) or a marginal basin (Tethys), both moderately deep, where pelagic muds were sporadically troubled by avalanches of bioclastic and oolitic sands, besides the usual mass flows or slides that involve deeper-water muds. So, it is indirectly proved that the guyots of the western MidPacific Mountains belonged to the world-encircling "Urgonian belt" as early as Barremian time, like many regions of the Tethyan domain. In and around the Vocontian Trough (French subalpine ranges), there is a good correlation between the occurrence and disappearance of bioclastic turbidites and, respectively, the subsidence and the drowning of the carbonate banks. Thus, the disappearance of carbonate clastics at Site 463 during the early Aptian suggests that the western guyots sank at that time, as did the Urgonian platforms in the French subalpine ranges.

The limestones cored at Site 463 show that lithification in coarse-grained carbonates probably can be achieved (with slight residual porosity) without emersion, producing the diagenetic features encountered in exposed calcarenites of the Vocontian domain.

Most astonishing are the cycles found especially in Aptian to Albian pelagic limestones of Site 463, which are like cycles known at some Atlantic sites and in the Vocontian Basin, where these alternations are under study. We think these cycles are related to climatic changes leading to fluctuations in planktonic productivity (with changes in nannofossil and even in microfossil assemblages), and to fluctuations in the influx of clay. Calculations both for Site 463 and the Vocontian Trough show that the deposition time of a single couplet spans a time (about 10,000-50,000 years) consistent both with the calculations of Dean et al. (1978) for similar Oligocene chalk-marl cycles of the Atlantic and the duration of isotopic stages of the Pleistocene.
\end{abstract}

\section{INTRODUCTION}

Barremian and Aptian limestones recovered at Site 463 indirectly have confirmed the existence of shallowwater carbonate complexes over the entire Mid-Pacific Mountains. Previously, evidence was found in the east, in rocks dredged on the upper slopes of seamounts (Hamilton, 1956), and later at DSDP Site 171 (Winterer et al., 1973). In both cases, the buildup of these complexes could not be dated accurately-between Aptian and Cenomanian time on Cape Johnson and Horizon guyots, before Cenomanian time on Horizon Guyot. However, Hamilton pointed out that the rudistidbearing fauna from Cape Johnson was perhaps Aptian. If so, (and because the last oolite-bearing layer also is in Aptian limestones at Site 463 , in the west), the early history of the main part of the chain might be more uniform than expected. Data are insufficient to reconstruct the history of sinking, which probably spanned a long time, from the Aptian (near Site 463) to the Late Cretaceous (Site 171), with renewed volcanic activity (ash in Aptian limestones at Site 463, Cenomanian ba-

\footnotetext{
${ }^{1}$ Initial Reports of the Deep Sea Drilling Project, Volume 62.
}

salt flow resting on shallow-water carbonates at Site 171).

As shown by both seismic profiles by the Glomar Challenger and the bathymetric map by Chase et al. (1971), the surroundings of Site 463 appear as a nearly flat-topped rise under 2600 meters of water, crowned by some likewise flat-topped seamounts. Hole 463 is in a saddle between two of the elevations (Fig. 1). A probably similar morphology, but necessarily shallower, also existed here during the first part of the Early Cretaceous, which would explain the shallow-water materials reworked by gravity processes into the deeper pelagic limestones cored at the site.

These allochthonous deposits are closely similar to those of the same age in the Vocontian Trough, which was then a small, moderately deep basin, surrounded on three sides by "Urgonian"" carbonate platforms, on the

\footnotetext{
2 The word "Urgonian" was created by d'Orbigny (1850) as an upper division of the Neocomian Stage. Unfortunately, he chose white, chalky, rudistid-bearing limestones outcropping near Orgon (southern France) as type strata for the ammonite fauna found cropping near Orgon (southern France) as type strata for the ammonite fauna found
elsewhere in bathyal limestones (as in the vicinity of Barrême). This explains why the laterelsewhere in bathyal limestones (as in the vicinity of Barrême). This explains why the later-
introduced word "Barremian" has been more widely used as a stage name. "Urgonian" became a facies name; at length, it was used in a wider sense (both stratigraphic and lithologic), for all shallow-water carbonate facies of the thick limestone sequences bearing the typical coral-hydrozoan-rudistid fauna, and whose ages range from Barremian through Albian. "Urgonian" is used here in the wide facies sense.
} 

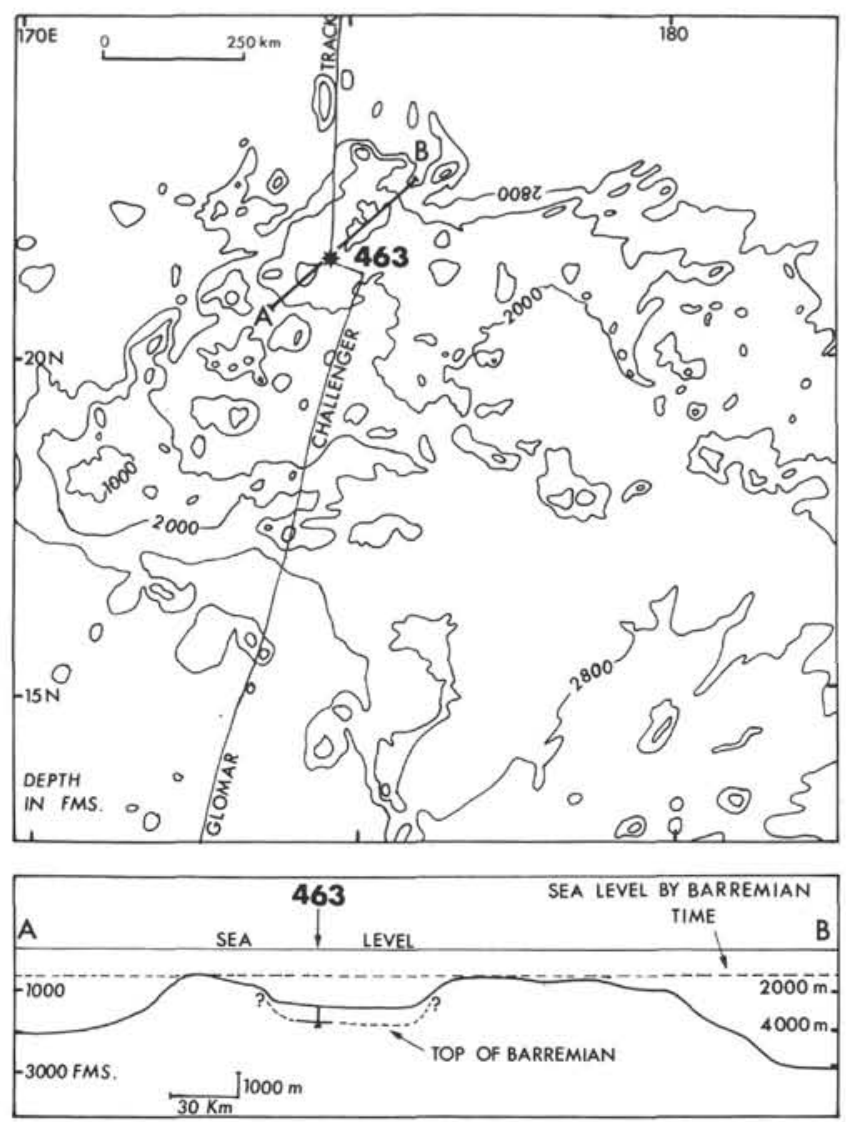

Figure 1. Bathymetric map of the western Mid-Pacific Mountains, and cross-section through Site 463 , which is in a saddle between two guyots (map from Chase et al., 1971). Cross-section shows present and reconstructed Barremian sea levels, for comparison with the Vocontian Trough (Fig. 2).

northern margin of the Tethys (Fig. 2). Recent studies have reconstructed in detail these carbonate banks and their history, from their progressive subsidence on shallow shelves in the early Barremian to their drowning by the end of the early Aptian and described the main faunal communities (Masse, 1976; Arnaud-Vanneau and Arnaud, 1976; Cotillon et al., 1979; Arnaud-Vanneau et al., 1979). In close connection with the spreading of the shallow-water carbonates, finger- or fanshaped bioclastic turbidite bodies were emplaced in the pelagic muds of the "trough," in addition to small, local slump and more voluminous debris-flow deposits, the latter coming from the edges of platforms (for details, see Ferry, 1978, 1979; Ferry and Flandrin, 1979). This basin is a useful reference for reconstruction of the ancient environment of Site 463. Comparison of Figures 1 and 2 shows the morphological similarities that probably existed in both areas by Barremian time (the guyots near Site 463, of course, are believed to have been the source of the shallow-water carbonates that gravitated into the saddle).

On the other hand, although its background was not oceanic, the Vocontian Trough is one of the few Cretaceous basins now exposed on land where true pelagic carbonates were deposed during the Early
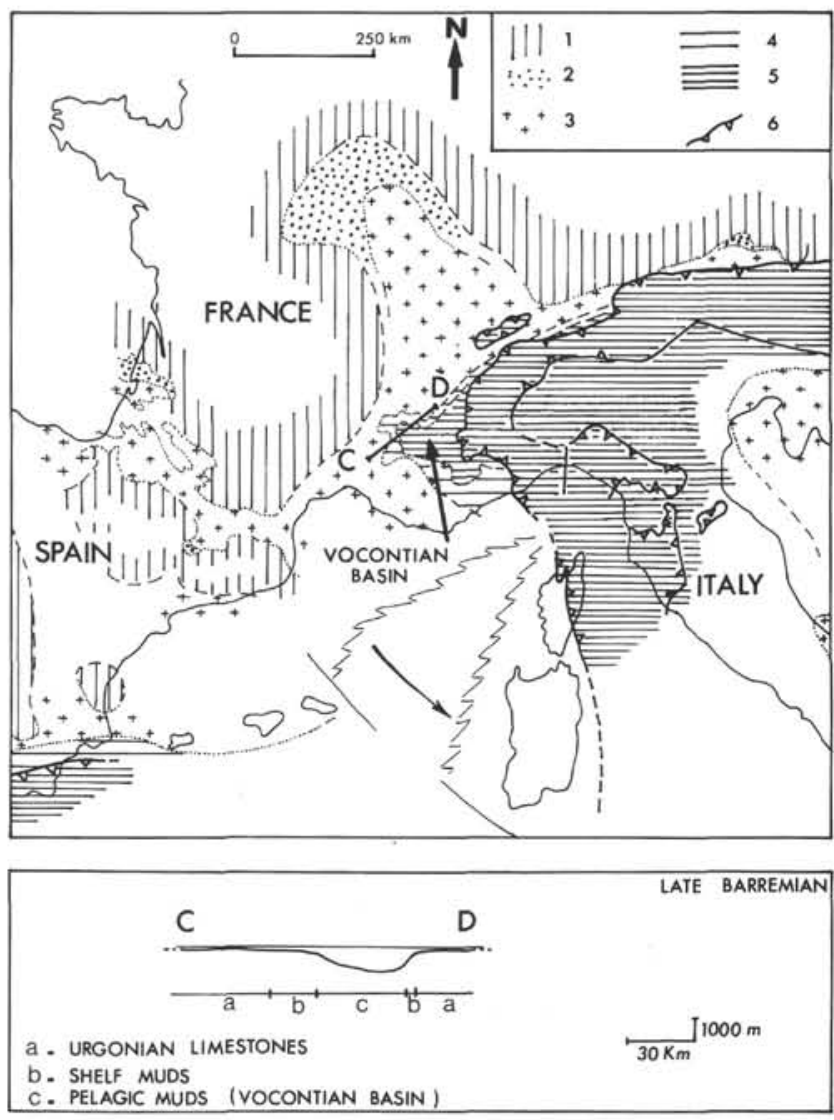

Figure 2. Facies map and paleogeographic interpretation (late Barremian through early Aptian), and late Barremian cross-section of the Vocontian Trough (mainly from Arnaud-Vanneau et al., 1979; Azema et al., 1975; Mathieu, 1965): 1, land areas; 2, terrigenous facies and coastal deposits other than Urgonian limestones; 3, Urgonian limestones (carbonate platforms); 4 , hemipelagic mud (shelf); 5 , pelagic mud (deep marine); 6 , main thrust faults of the Alpine Belt. The 1000-meter water depth for the late Barremian is deduced both from calculations based on slope-values required for gravity-flow processes and from the discovery of deep-water mollusk and echinoid faunas, now under study.

Cretaceous, in sequences where limey beds and marly layers monotonously alternate. The autochthonous facies at Site 463 surprisingly shows this same basically cyclic pattern, which is also encountered in the Lower Cretaceous of many Atlantic sites, as discussed by Dean et al. (1978). This (and also initial studies carried out in French subalpine ranges) leads us to emphasize the importance of such a facies to the understanding of the processes governing pelagic sedimentation above the calcite-compensation depth $(C C D)$ in the oceans-at least during the Cretaceous, this was perhaps connected with oscillations of climate.

\section{MATERIALS}

The Lower Cretaceous sequence drilled at Site 463 is mainly calcareous, obviously deposited above the CCD. As at many DSDP sites, sediments are lithified downhole, but still bear some porosity, unlike coeval deposits exposed on land. The sequence can be described as a pile of cyclic pelagic deposits, thickened by many layers of 
reworked material (Fig. 3A), a section very similar to those studied in the Vocontian Trough (Fig. 3B). This interlayering is evidence of the allochthonous character of the reworked material; sharp, erosional basal contacts (when recovered) provide additional evidence (Plate 1, Fig. 3). In the pelagic deposits, the cyclic pattern is obvious only from the Aptian through the Al- bian; we believe it is also present below, but masked either by poor recovery or synsedimentary reworking.

The frequency of allochthonous deposits, especially those containing shallow-water materials, rapidly drops from the upper part of the Barremian to the lower Aptian. Above, slump deposits contain only pelagic mudstones. This suggests that the drowning of the source of

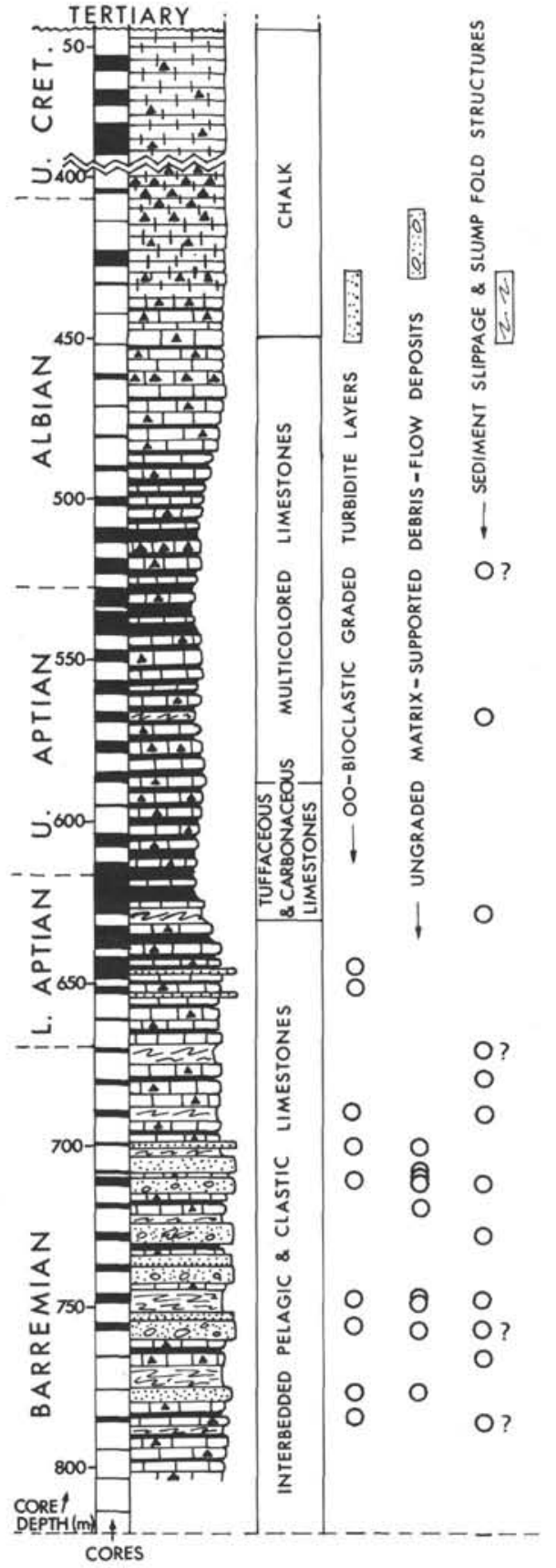

A

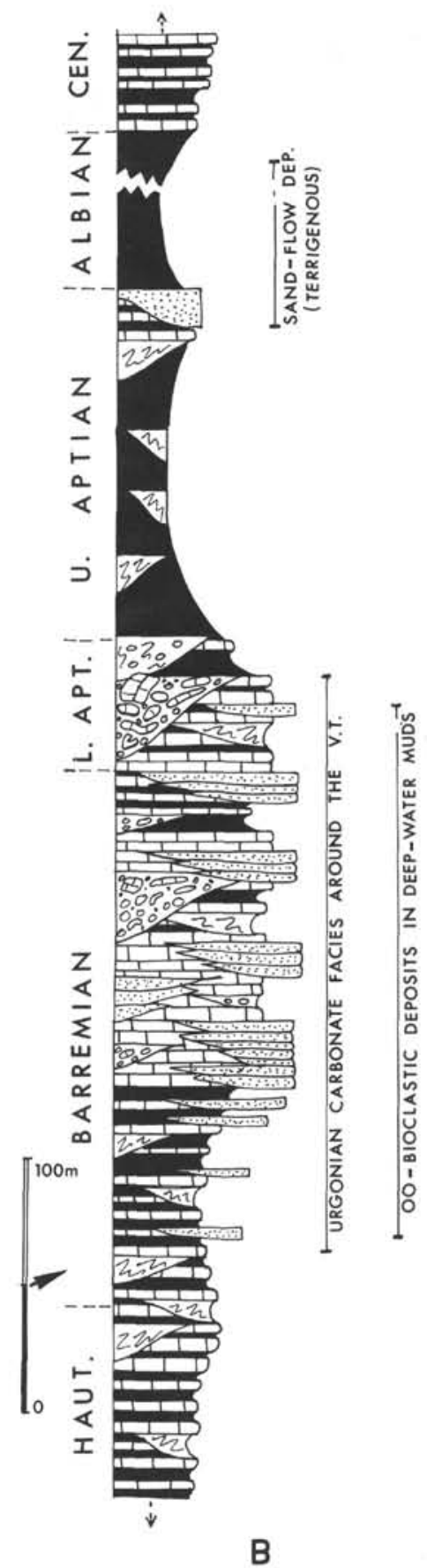

Figure 3. Interpretation of the Cretaceous section cored in the Site 463 (A), in the light of similar deposits outcropping in the French subalpine ranges (B) (composite section). In both cases, alternating pelagic limestones and marls have intercalated mass-flow deposits. The black color used to represent the marly interbeds in pelagic deposits does not correspond to the true color. 
shallow-water carbonates was achieved by the end of the early Aptian, as in the French subalpine ranges. The age of their settlement is unknown, because drilling ended in Barremian limestones.

Our contribution is based mainly on examination of sedimentary structures in core photographs. To complete shipboard descriptions, we have studied 12 extra samples, each by thin-section, X-ray diffraction on both powdered bulk samples and carbonate-free residues, and scanning (SEM) and transmission (TEM) electron microscopy (the latter for decarbonated, clay-sized fractions). Facies of the studied samples fall into two groups: four coarse-grained Barremian limestones, and eight Aptian through Albian fine-grained pelagic limestones. Among the latter are two pink-red marls, and six white or very light-colored limestones.

\section{SHALLOW-WATER MATERIALS}

Shallow-water materials are mostly calcareous, usually sand-sized, consisting of rather monotonous admixtures of oolites and coated grains, with variable amounts of skeletal debris (principally bivalves and echinoids) - and many other elements. Bivalve debris is too comminuted to be identified, so the presence of rudistids is not certain.

However, judging from the diversity of shell-wall structures, this fauna was probably well diversified (there are also at least three types of echinoid spine sections). Minor constituents are dasycladacean (Acicularia) debris, rare stromatolite fragments, rather scarce foraminifers (miliolids, Lenticulina; unfortunately no orbitolinids for dating, but among the small agglutinate forms Dorothia sp. cf. D. levis at 463-85-1, 46-48 $\mathrm{cm}$ - an Albian form recently encountered in the lower Barremian of the French subalpine ranges by $\mathbf{A}$. Arnaud-Vanneau [pers. comm., 1979]), and other, unrecognizable grains (because of micritization, or recrystallization, or both). Corals are absent, but this does not disprove the existence of reefs on the guyots; there were reefs around the Vocontian Trough, where such debris is rather scarce in turbidite deposits, but common on platforms.

This material sometimes occurs in matrix-supported sediments as rounded, gravel-sized clasts with regular fringes of calcite crystals around the grains (the pore spaces later being filled by a calcite mosaic); this is evidence for early-probably submarine-cementation, before reworking. Such types of cements are common in "outer sands" on Urgonian platforms.

Shallow water materials throughout the section also include primary non-biogenic grains, which are usually sparse: (1) glauconite-replaced echinoid debris or wellrounded glauconite grains, probably shelf-derived, as also in the Vocontian Trough, where this mineral never occurs in deep-water muds (except in interlayered massflow deposits), but in those of the outer shelves; (2) sand-sized volcanogenic clasts and very fine black grains believed to be basalt fragments; these may correspond either to erosion products of remnant volcanic islands mixed with carbonate sediments before gravity-reworking, or, more likely, to submarine erosion of the volcanic substrate of the carbonate complexes by sediment flows.

It is obviously adventurous to speculate on the carbonate capping of the guyots on the basis of what gravitated into the saddle, but one fact is clear: such mainly oolitic material had to require a very shallow, open bank or shoal or gently plunging shelf, rather than a fringing reef complex growing up around a subsiding volcano in step with the drowning or a more-mature, atoll-like structure. Moreover, the duration of oolite production over several millions of years is probably evidence of a subtle balance between subsidence and carbonate production.

Earlier dredging on Cape Johnson Guyot had shown that the reef biota ${ }^{3}$ reached the edge of the bank there. On Urgonian platforms around the Vocontian Trough, as reconstructed by the authors cited above, there was always a more-or-less wide zone of "outer bioclastic sands,"' off the fringe of reef patches, where most of the Urgonian oolites were also produced (Masse, 1976). Materials of basin turbidite deposits seem to have originated mainly in this zone. If the zonation of the French Urgonian platforms can be applied to western Mid-Pacific Mountains guyots, the coarse-grained carbonates recovered at Site 463 suggest that there was a permanent, very shallow shelf area in the neighborhood. However, they can neither prove nor disprove the existence of true Urgonian facies, like those of the eastern guyots.

In any case, it is obvious that the entire Mid-Pacific Mountains belonged to the Early Cretaceous "Urgonian belt" (Fig. 4). Citing affinities between coral and rudistid faunas from the Tethys to the Pacific, Hamilton (1956) pointed out that there was probably an easy east-west circulation of surface marine waters around the entire Earth at this time, leading to wide distribution of larvae. This idea is strengthened by new studies on bivalve and gastropod faunas from the Tethys to the Caribbean (O. Macsotay, pers. comm., 1979).

The location of the Mid-Pacific Mountains, backtracked according to Lancelot and Larson's (1975) hypothesis to the early Aptian, near the southern limit of the "belt" (Fig. 4) is also noteworthy. The guyots were perhaps built and began to subside earlier than previously thought, so that their flat tops still were in the photic zone when they crossed the tropical/equatorial band, where formation of carbonate complexes was possible. This is perhaps a way to explain the style of these complexes-which do not seem to have been of the atoll type, as are the recent Pacific complexes.

\section{DIAGENESIS IN COARSE-GRAINED LIMESTONES}

Like those in the Vocontian Trough, the coarsegrained limestones of Site 463 probably occur as lenses in pelagic mudstones. Because the site has never emerged, it is difficult to believe that fresh ground waters, coming from possibly exposed banks, have cir-

\footnotetext{
${ }^{3}$ Some rudistid genera might have been represented in this biota, although rudistids usually characterize the inner platform, according to Masse (1976, fig. 89).
} 


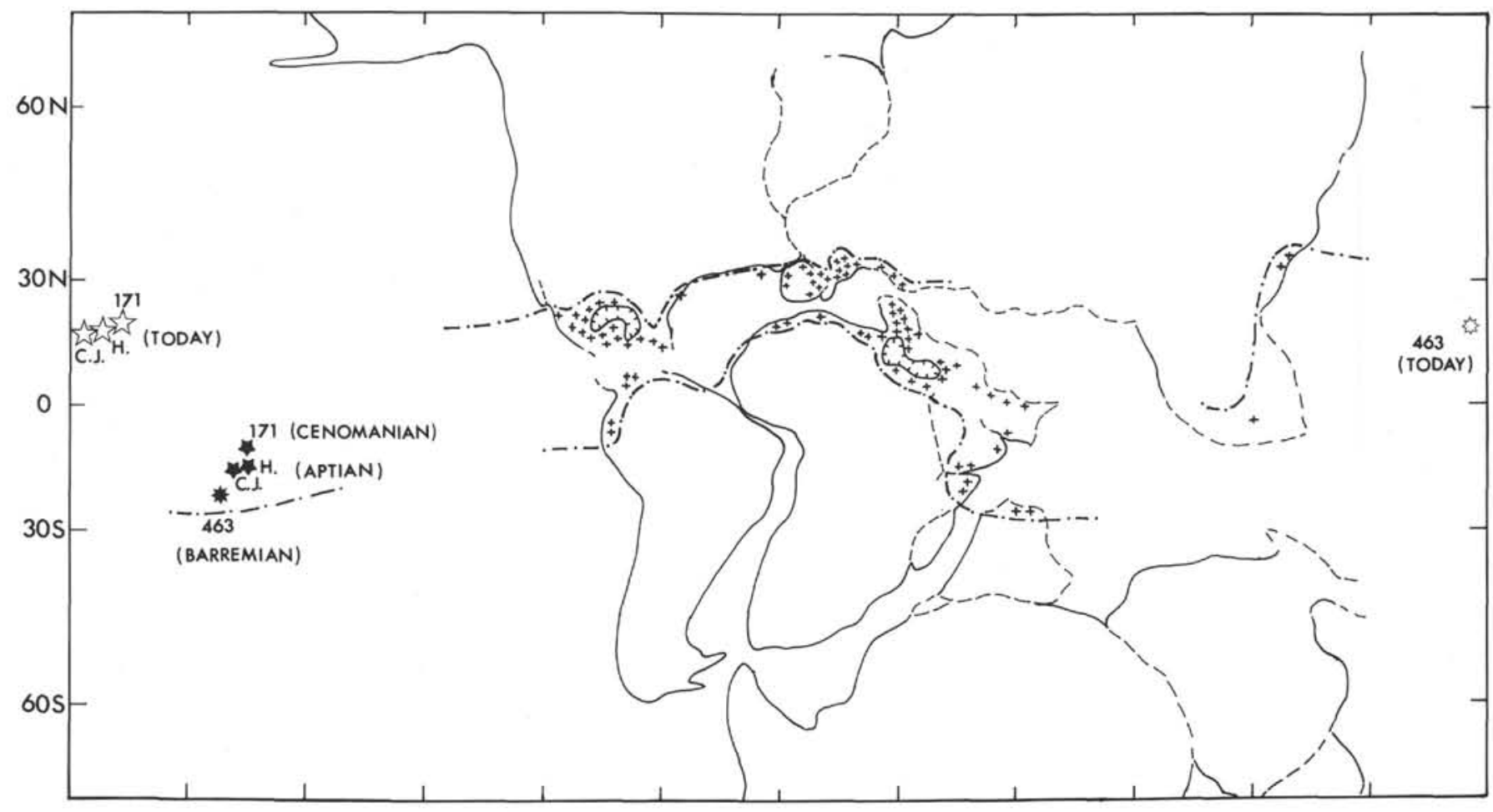

Figure 4. Distribution of thick Lower Cretaceous, rudistid-bearing carbonate sequences (crosses) in the "Urgonian belt"' (from many sources; see also review in Arthur and Schlanger, 1979). The Mid-Pacific Mountains guyots have been back-tracked according to Lancelot and Larson's (1975) hypothesis of an average northwestern motion of the old Pacific plate throughout its history. Paleocontinental map from Smith and Briden (1977). DSDP sites are numbered, Horizon and Cape Johnson guyots indicated by letters.

culated in these deep-water lenses. On the other hand, if shallow-water derived materials had been exposed to meteoric waters while on the banks (before being reworked), they probably would occur only as gravels or cobbles in debris-flow deposits at Site 463, owing to early cementation. We believe that these materials scarcely could be displaced as loose sands in turbidity currents. Thus, we think that the diagenetic features we have found in coarse-grained limestones of Site 463 have formed in situ, at moderate burial depths, without exposure to fresh water.

The following features were observed:

1) All expected primary carbonate minerals (aragonite from bivalves and gastropods, $\mathrm{Mg}$ calcite from echinoids) are stabilized to low-Mg calcite.

2) Recrystallization features are common: in some grains, probably first in aragonite, a stage of dissolution seems to have occurred before the later filling of cavities by a calcite mosaic which does not contain aligned inclusions or other ghost structures. There is sometimes remnant moldic porosity (Plate 1, Fig. 1), a feature connected with the influence of meteoric waters by many authors. The same type of mosaic, or even a single calcite crystal, partly or entirely fills some voids resulting from dissolution of radiolarians.

3) Other debris apparently has retained its foliated structure (bivalves), but, under crossed nicols, a superimposed, discordant, mosaic-like extinction pattern is seen, suggesting neomorphic in situ replacement.

4) Echinoid ossicles may show acute, saw-shaped, syntaxial overgrowths which must result from the re- crystallization of the surrounding micrite. They are not cement formed before reworking. This echinoid debris often is replaced by glauconite, by spherules or irregular patches of chalcedony, or by pyrite. The pyrite was formed before compaction, as shown by the crushed lamination, in the upper part of a graded bed, on both sides of a large, rounded pyrite grain that grew in the sediment.

5) In grain-supported sediments, the micrite matrix is here and there recrystallized into microspar.

6) Two kinds of micritization occur. The first results in the classic micrite envelopes described by Bathurst (1971). The second is manifest in a more-enigmatic, non-centripetal, nebulous chalkiness of grains, especially obvious in oolites, and leads to the loss of their internal structure (Plate 1, Fig. 1). Such micritization does not resemble the selective leaching of nannocrystallites of skeletal fragments described by Alexandersson (1972) in undersaturated, cold sea water. It does not occur in calcarenites of the Vocontian Trough, but seems to show similarities with that (still not understood) encountered in chalky Urgonian limestones of southern France: in both cases, as seen by SEM, the porous micrite in "decayed" grains consists of slightly interlocking, euhedral crystals of nearly the same size.

Furthermore, there are obvious signs of compaction:

1) Pressure welding of grains in grain-supported sediments (stylolite-like grain contacts in Plate 1, Fig. 1).

2) Microscopic solution seams in matrix-supported sediments (Plate 1, Fig. 2), revealed by the irregular penetration of the resin used to consolidate the samples 
before making the thin sections. Such seams do not exist in autochthonous pelagic micrites, or seem to be fainter. Dissolution under pressure may have furnished large amounts of $\mathrm{CaCO}_{3}$ for lithification, as suggested by Bathurst (1971).

Most of these features also can be observed in calcarenite beds of the Vocontian Trough. Finally, one of the most obvious differences between limestones of both areas is the porosity: nearly nil in the exposed area; not measured, but consistently higher at Site 463 .

Another difference is the wide variation in the preservation of the admixed radiolarians, sometimes in the same thin-section: well-preserved, entirely dissolved, partly or completely filled either by silica or by calcite at Site 463; always calcitized in the Vocontian Trough.

\section{MASS-FLOW DEPOSITS}

The material described above is encountered only in mass-flow deposits. These deposits also contain various amounts of pelagic material, sometimes dominant amounts. There are three types of allochthonous sediments at Site 463: (1) grain-supported, graded; (2) matrix-supported, ungraded; (3) slumped.

The first type occurs regularly throughout, up to 463-73-3 (lower Aptian), the second only in the lowermost part of the section, up to 463-80-1 (upper Barremian), and the last, very frequent in Barremian deposits, is still encountered at 463-65-3 (lower Aptian), possibly above (Fig. 3). Some typical cores are figured in Plates 1 and 2.

The grain-supported, graded deposits basically have a packstone texture, sometimes masked by recrystallization of the micrite, but when grains are entirely interlocked by pressure welding, one suspects matrix-free material. The layers are usually thin, from a few centimeters to $30 \mathrm{~cm}$. Grading is obvious, with sand-sized material at the base, becoming finer and horizontally laminated at the top. Such layers can be termed AB Bouma sequences and should represent deposition from highly turbulent turbidity currents, according to the classification of Middleton and Hampton (1976). There is only one thick, massive, graded bed (463-85-1), at least $115-\mathrm{cm}$ thick. Despite its thickness, its more progressive grading, and the lack of faint lamination throughout, it may also correspond to a very turbulent flow, as seen in the Vocontian Trough, where almost ungraded calcarenite beds, 3- to 5-meters thick, show large, intricate flute casts at their sole.

These deposits often contain small clasts of pelagic sediment, whose sizes are similar to or slightly coarser than those of oolites and skeletal debris. Such clasts are evidence of erosion during avalanching of shallowwater sands. At first sight, it is hard to understand how the usually very watery muds of the bottom could form durable clasts within a turbulent flow, without the protection of a cohesive, muddy matrix, as in pebbly mudstones. However, the clasts may have been produced a few tens of seconds before deposition began, older clasts already having been destroyed. Thus, they do not imply erosion of considerably older, more-compacted muds on slopes peeled by successive slope failures.

The graded layers do not always correspond to single events. At 463-81-1, 111-114 cm, a 3-cm-thick laminated layer probably represents a turbidite bed, closely linked to the emplacement of the underlying debris-flow deposit. Such an association between two types of processes is commonly encountered in Vocontian deposits and elsewhere, in many reef- or bank-margin environments (Mountjoy et al., 1972).

The matrix-supported, ungraded deposits are on the average thicker than the graded ones. They basically have a wackestone texture (Plate 1, Fig. 2) and show evidence of mixing: usually gravel-sized (more rarely pebble-sized), radiolarian-rich clasts of pelagic sediment or little folds of pelagic sediment-beside various amounts of the shallow-water-derived materials described above-all "float" in a micrite matrix. The matrix is mainly pelagic as shown by its high content of nannofossils and radiolarians (often voids due to dissolution of radiolarians in the clasts discussed above). Such pebbly mudstones (Plate 1, Figs. 3 and 4; Plate 2, Fig. 4), according to Middleton and Hampton (1976), are debris-flow deposits in which matrix strength provides the main support, which could have retarded the disorganization of the soft pelagic clasts or folds during transport over some distance.

In the Vocontian Trough, coeval deposits were mainly removed from muddy slopes or edges of platforms, sometimes from the partly cemented "outer sands," judging from their content. They always represent rather long displacements, at least 10 to $15 \mathrm{~km}$, down to about 1000 meters water depth. This is also true in the Mid-Pacific Mountains, as shown both by the high content of shallow-water materials, and by early-cemented oolitic clasts. Sand avalanches began on the bank edge and incorporated deep-water muds during transport.

Slump features are very abundant, especially in the Barremian, although not always obvious. Judging from many well-exposed examples in the French subalpine ranges, we think that many, if not most, of the wavy, wispy laminations - or even some of the parallel laminations (Plate 2, Fig. 4)-could represent various degrees of deformation by slumping or surficial creeping of very soft muds. If so, the Barremian deposits perhaps are almost entirely displaced. This does not necessarily imply important stratigraphic perturbations.

The most-typical core (Plate 2, Fig. 1) shows characteristic features encountered in folds of all Vocontian slump deposits (a typical example in Plate 2, Fig. 3) and elsewhere, as at DSDP Site 364 (Bolli, Ryan, et al., 1978). The final product of such multiple folding and shearing can be a layer laminated throughout, with only slight undulations, and no (or scarce) apparent folds, because the laminae are themselves the flanks of flattened folds. Likewise there are pebbles or cobbles of structureless pelagic material, rolled along shear planes. Similar features, with drawn and rolled folds, can be observed by slowly mixing watery muds of different colors. Such deformation is consistent with the usual soft- 
ness and even the "soupy" character of the bottom muds. Additional evidence for reworking is seen in the oolites and skeletal debris (white, sand- or gravel-sized clasts) which occur throughout (Plate 2, Figs. 1 and 4).

In a general way, there are all transitions between features which probably indicate the beginnings of creep-with only some shear planes (Plate 2, Fig. 2)-to those which indicate severe deformation (Plate 1, Fig. 4).

In the Vocontian Trough, slumps have involved only pelagic sediments, and thus are believed to represent slight displacements on gentle slopes in deep water, or on glacises down the platform margins. Site 463 was probably on such a glacis at this time, as indicated by evidence of double gravity reworking in the deposits. In our opinion, the oolites in slump layers imply reworking of previously deposed turbidite beds, sandwiched in pelagic muds up-slope. Moreover, features like tensional microfaults (Plate 1, Fig. 4) suggest that slump movements could begin even at the site.

It is not possible to deduce the water depth at Site 463 by Barremian time on the basis of the deposits. If the Barremian morphology was later simply drowned (no faults), one can calculate roughly that the maximum water depth was less than 1700 to 1800 meters, assuming that not much sediment was deposited on carbonate banks after their subsidence. This assumption probably is not valid, and the initial depth of the saddle $(1500 \mathrm{~m}$ ?; Fig. 1) perhaps was not very different from the water depth (nearly $1000 \mathrm{~m}$ ?) inferred for the Vocontian Trough at the same time (Fig. 2).

\section{AUTOCHTHONOUS CYCLIC DEPOSITS}

When this study began, our attention was not focused on the problem of cycles in calcareous pelagic deposits outside the Vocontian Trough. Careful investigation of core photographs from many DSDP sites then revealed to us the worldwide occurrence of this kind of cyclic deposit (plateaus of the Pacific, Atlantic margins), representing deposition above the CCD and in very quiet environments, with no interference from large volumes of terrigenous sediment on deep-water fans, from volcanogenic materials, or from deep oceanic currents. In view of the small number of oceanic samples studied here, the considerations given below are essentially speculative.

Alternations of pelagic limestones and marls were deposited in the Vocontian Trough from the Late Jurassic through the Late Cretaceous. They are under study (Cotillon et al., in press). The best example of these alternations (Plate 3, Fig.1) is very similar to Barremian deposits cored in the Atlantic (Site 367; Dean et al., 1978), which are a monotonous pile of light-gray limestone beds $\left(80-95 \% \mathrm{CaCO}_{3}\right)$ and more-argillaceous (mainly marlstones) dark-gray or black interbeds (40$70 \% \mathrm{CaCO}_{3}$ ). In other examples, either beds or interbeds dominate, producing what may be called "calcareous alternation" (a few, thin, marly layers, or even marly films between beds; Plate 3, Fig. 2), or "marly alternation" (a few, thin, limy beds among marls).
Limestone-marl and marl-limestone transitions (Plate 3, Fig. 3) are progressive, although usually abrupt, but the sharpness of some contacts may have been destroyed by bioturbation. Bioturbation is strong in beds more diluted by interbeds (Plate 3, Fig. 3). It can even disappear (Plate 3, Fig. 4), as in coeval deposits off the African margin (Dean et al., 1978). This may be connected with anoxic events or with conditions operating against bottom life in the Vocontian Trough, where the uniform gray or even black color of sediments throughout the Mesozoic section, a sometimes-reduced benthic fauna (Plate 3, Fig. 4), the ever-present pyrite, the slightly abnormal boron contents, and paleogeographic considerations are evidence for an oxygen-poor basin (Porthault, 1978), but only with regard to bottom waters (Urgonian facies on the surrounding banks). The calcareous fractions, both in beds and interbeds, results mostly from "pelagic rain" (nannofossils and globigerinids), as strongly suggested by the wide occurrence of bedssome as thin as a few centimeters-that have been traced (Cotillon et al., in press) over the entire basin (more than $10,000 \mathrm{~km}^{2}$ ).

Except for the colors, Aptian through Albian cores from Site 463 show this alternating pattern, with either a very gradational or more-abrupt transition-or even sharp contacts between light-colored limestone beds (light-gray, white, pink, green) and darker, more argillaceous interbeds (reddish-gray, red, or black; Plate 3, Figs. 5, 6, 7). Beds are bioturbated. This bioturbation (flattened large burrows, thin Chondrites) is less prominent in some marly interbeds, especially when black (Plate 3, Fig. 6), but also sometimes in the red interbeds, when dark-in other words, in a general way, apparently when clay content rises, perhaps independent of the color of sediment. Thicknesses of couplets vary widely, from several centimeters to more than a meter, but it is difficult to correctly interpret these fragmented cores, because of partial recovery, suspected synsedimentary slippage features in some pieces, and the frequency of lithologies intermediate between limestone and marl that may weaken the cyclic aspect.

From shipboard carbonate-bomb analysis, carbonate content of limestone beds is 75 to $85 \%$, but can drop to a few percent, probably because of silicification. The remaining 15 to $25 \%$ is mainly silica and very small amounts of clay minerals (smectite) (SEM, TEM, $\mathrm{X}$-ray). Silica principally appears as nannoclusters of euhedral diagenetic quartz (Plate 4, Figs. 1,5) that grew in the pore space between nannofossils or in molds of dissolved radiolarians before carbonate lithification, as proved by their embayment by calcite overgrowths (Plate 4, Fig. 6). These clusters occur in autochthonous deposits as well as in slumped layers and in the matrix of debris-flow deposits. They apparently have not been cited previously in the Initial Reports of DSDP. Diagenetic quartz, as single slightly coarser nannocrystals, also occurs in limestone beds of the Vocontian Trough, in connection with the usually high content in now-calcitized radiolarians. Such amounts of silica are perhaps higher for pelagic limestones than expected on the basis of cherts. 
Carbonate content of interbeds drops to 60 to $70 \%$. Scarcer quartz clusters also occur, but carbonate-free residues consist mostly of clay minerals. In our samples, clay minerals are mainly very fine-grained dioctahedral smectite, with small amounts of larger crystals of illite (X-ray, TEM). The illite is recorded by X-ray diffraction only in interbeds, perhaps because of their higher clay content. Similar assemblages were found on Magellan Rise (Zemmels and Cook, 1973).

There are no apparent differences at Site 463 between beds and interbeds. On the contrary, we record sharp and systematic differences in clay assemblages of beds and interbeds of the Vocontian Trough, throughout the whole Cretaceous sequence, suggesting that cyclic, climate-induced modifications of soil formation and erosion on land close to the basin led to cyclic changes in the detrital assemblages supplied to the trough. Changes in crystallinity of clay minerals are also found in Oligocene cycles of the Atlantic at Site 366 (Dean et al., 1978). The proximity of land areas may explain such variations in both cases. Several thousands of kilometers offshore, possible agents like surface or intermediate nepheloid layers would mainly carry the finer materials. Thus, initial differences could be weakened strongly.

There are at least two main ways a limestone-marl alternation is formed:

1) First, assuming that neither detrital influx nor carbonate productivity vary, then the cyclic occurrence of (selective) dissolution of nannofossils can only concentrate the clays to build marly interbeds. Such an explanation is favored by Dean et al. (1978) to explain Oligocene chalk-marl cycles on Sierra Leone Rise (Site 366 ), where changes in both clay mineral and nannofossil assemblages are recorded between "beds" and "interbeds."

2) Second, supposing that all factors vary in a primary way, the alternation closely reflects variations of the environment, both in marine waters and on land. The cycles are then due to a subtle balance between carbonate production in surface waters and detrital influx (clays, eventually land-derived organic matter), the two varying both in quantity and in quality but not in phase. Only climate can act in such a way on the environment. Such an explanation is favored by Cotillon et al. (in press) to explain the changes in nannofossil, microfossil, and clay-mineral assemblages between beds and interbeds in the moderately deep Vocontian Trough during the Early Cretaceous.

Although we do not find clear differences in claymineral associations, we also favor this interpretation for the Lower Cretaceous alternations of Site 463; dissolution of carbonate can be excluded because of the probably moderate deposition depth (see above). Both at Site 463 and in Vocontian Trough, nannoconids are abundant and sometimes dominant over coccoliths in limestones (Plate 4, Figs. 1, 2), but they disappear in more-argillaceous layers, where we have found only coccoliths (Plate 4, Figs. 3, 4). This observation was made for the first time in the Vocontian Trough by Noel (1968) and more recently by Manivit (1979). Likewise, the micropellets ( $40-80 \mu \mathrm{m})$ encountered in the marls of both areas contain only coccoliths, scarce radiolarian spines, foraminifer wall fragments, and unrecognizable particles, but no nannoconids-even fragmented or partly dissolved-suggesting that plankton consumers did not find them in surface waters during periods of high clay influx. In the Vocontian Trough, conditions were probably even more differentiated than in the Pacific between times of limestone and marl deposition: globigerinids for the most part are concentrated in marls, and radiolarians in limestones. Clearly, the composition of the plankton was oscillating. Such changes in microfossil assemblages are not as strong at Site 463, although we have always found higher amounts of radiolarians in limestones, and very few in marls. Yet, the number of studied samples is too small to be sure.

Calculations of the deposition time of a single limestone-marl couplet in the hypostratotypic section of the Valanginian Stage at Angles (Vocontian Trough) have given an average value between 13,500 and 20,000 years, using the Cretaceous time scale of Van Hinte (1976). If the thicknesses of couplets are taken into account, this range is expanded to 8000 to 40,000 years. For the Barremian, we have found in the same section an average value of 30,000 to 35,000 years. For Site 463, it is difficult to perform such calculations, because of the very fragmented cores with many pieces in artificial contact. Nevertheless, using the average thickness of couplets $(15-40 \mathrm{~cm})$ observed in well-cored intervals, the total number of cycles for upper Aptian to lower Albian deposits, in which the limestone-marl alternations are most obvious at Site 463, should be between 210 and 560 for a period of about $8 \mathrm{~m}$.y. This gives an average deposition time between 14,000 and 38,000 years. These durations are consistent with those calculated by Dean et al. (1978) for different kinds of cycles encountered in Atlantic sites off the African margin, mainly in Tertiary deposits. Processes involved there in the formation of the alternations are not the same, but are also probably climate-induced. Similar durations can be found in isotopic curves for the Pleistocene (Shackleton and Opdyke, 1976; Emiliani, 1978), supporting the idea of climatic control of pelagic sedimentation as early as the Cretaceous.

Likewise, the widespread formation of these limestone-marl alternations during the Early Cretaceous (Fig. 5) clearly shows that they are a fundamental facies of intermediate depths over the world ocean, and thus must result from general factors, acting on a global scale. Comparison of Pacific (red) and TethyanAtlantic (gray/black) alternations shows that the alternation phenomenon must be distinguished from superimposed features. The most obvious among these features is the reducing character of the deep-water muds of restricted basins like the Vocontian Trough and the basins of the early Atlantic, leading to the deposition of gray marls or even black shales. On the other hand, in the Pacific only a few such deposits are known at some sites, in the Lower Cretaceous. The model of Thiede and van Andel (1977) may elegantly explain such differences: whereas the basins of the Atlantic and of the 


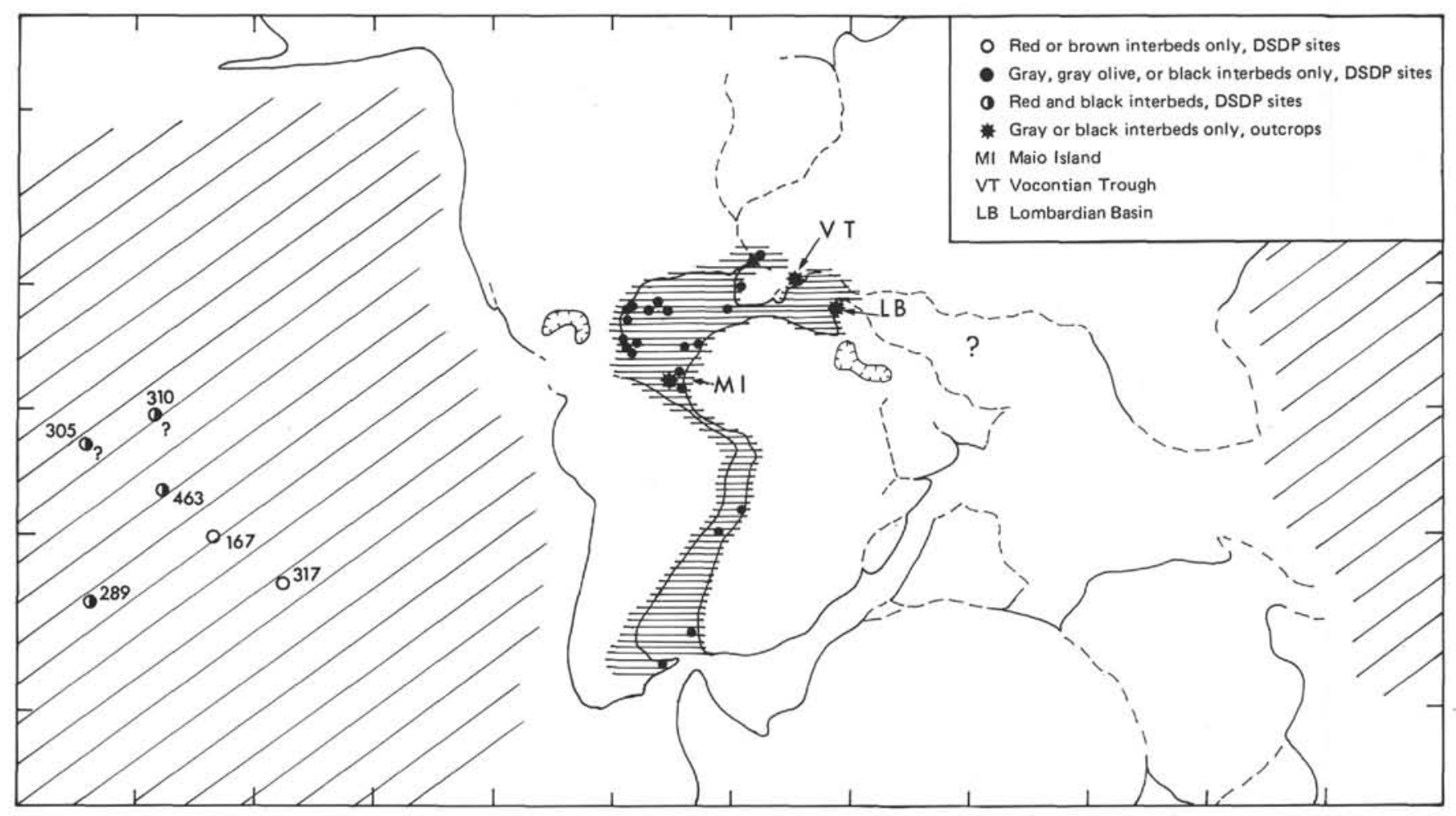

Figure 5. Distribution of sites where pelagic limestone-marl alternations were deposited during all or part of the Early Cretaceous (data mainly from DSDP Initial Reports). The beds are usually light-colored white, light-grey, green, or pink. The Pacific sites have been back-tracked about 105 m.y.

Tethys were still characterized by a slow turnover of bottom waters, leading to poor bottom-life conditions, and even to anoxic events (see synthesis of Arthur and Schlanger, 1979), an oxygen-minimum zone has intersected only some of the Pacific guyots at some times.

This difference suggests that bottom waters of the Pacific and the Atlantic probably did not communicate between the two Americas, while unlike surface waters did communicate ('Urgonian belt").

\section{CONCLUSIONS}

Lower Cretaceous deposits cored at DSDP Site 463 are very similar to those which outcrop in the French subalpine ranges, suggesting that the paleoenvironments were probably alike. Both resulted in:

1) Shallow-water carbonate facies on the surrounding banks (either oceanic flat-topped guyots or marginal platforms) during the Barremian through the early Aptian. This shows that the Mid-Pacific Mountains belonged to what may be called a world-encircling "Urgonian belt." These facies are older than expected from previous data.

2) Deposition of pelagic limestone-marl alternations off the banks, at intermediate depths (probably 1000$2000 \mathrm{~m}$ in both cases).

3) Gravity reworking of materials from the banks and their slopes, into the pelagic facies.

A comparison of mineralogical and faunal content of pelagic marls and limestones in both domains shows differences which-although not as strong in the Paci- fic-suggest that deposition was controlled by cyclic changes in surface marine waters and in influx of terrigenous materials. These changes were probably both climate-induced, but did not act in phase. Periods of high influx of terrigenous materials probably resulted in diminished planktonic production (only coccoliths are well represented among nannofossils), and periods of low influx probably permitted plankton blooms (nannoconids, coccoliths, and radiolarians).

The worldwide formation of these pelagic alternations during the early Cretaceous (and probably from the Jurassic to perhaps the Pleistocene) strengthens the climatic hypothesis and is opening a field for new research, especially regarding paleoclimates and their action on all aspects of pelagic sedimentation above the CCD.

\section{ACKNOWLEDGMENTS}

We thank O. Macsotay, Ministerio de Energía y Minas, Caracas, Venezuela, for his help regarding the geology of the Caribbean domain, for numerous discussions about the global distribution of bivalve and gastropod faunas during the Early Cretaceous, and for reviewing the manuscript. Professor P. Cotillon, University of Lyon, D. Bernouilli, University of Basel, and Y. Lancelot, now at Scripps Institution of Oceanography, also have reviewed this paper, and we warmly thank them for their comments. Many ideas regarding the genesis of pelagic limestone-marl alternations have merged during discussions with colleagues of the Lyon-based group for the study of alternations (GREAL), led by Cotillon, who are now dealing with pelagic cyclic deposits of the Vocontian Trough. Thanks are also due to Mrs. A. Arnaud-Vanneau, Grenoble, who identified the foraminifers in thin-sections, and P. Bernier, Lyon, who dealt with the algae. SEM photographs were taken at the Centre de Microscopie Electronique Appliquée à la Biologie et la Géologie, Lyon. Research funds 
originated from the Centre National de la Recherche Scientifique, France, through the Laboratoire de Paléontologie Stratigraphique et Paléoécologie, Lyon. Finally, we thank the DSDP staff at Scripps Institution of Oceanography for quickly providing the core samples and additional materials.

\section{REFERENCES}

Alexandersson, E. T., 1972. Micritisation of carbonate particles: processes of precipitation and dissolution in modern shallowmarine environments. Bull. Geol. Inst. Univ. Uppsala, n. ser. 3, 7:201-236.

Arnaud-Vanneau, A., and Arnaud, H., 1976. L'évolution paléogéographique du Vercors au Barrémien et à l'Aptien inférieur (Chaines subalpines septentrionales, France). Géol. alpine, 52: 5-30.

Arnaud-Vanneau, A., Arnaud, H., Charollais, J., et al., 1979. Paléogéographie des calcaires urgoniens du Sud de la France. Colloque sur l'Urgonien des pays méditerraneens (10-12 Sept. 1979, Grenoble), Geobios, 4:363-383.

Arthur, M. A., and Schlanger, S. O., 1979. Cretaceous "oceanic anoxic events" as causal factors in development of reef-reservoired giant oil fields. Bull. Am. Assoc. Petrol. Geol., 63:870-885.

Azema, J., Foucault, A., Fourcade, E., et al., 1975. Le Crétacé dans la partie orientale des zones externes des cordillères bétiques. Primer Coloquio de Estratigrafica y Paleogeografica del Cretacico de España, Enadisma Ediciones, ser. 7, No. 1:159-217.

Bathurst, R. G. C., 1971. Carbonate sediments and their diagenesis: Amsterdam (Elsevier).

Bolli, H. M., Ryan, W. B. F., et al., 1978. Angola continental margin-Sites 364 and 365. In Bolli, H. M., Ryan, W. B. F., et al., Init. Repts. DSDP, 40: Washington (U.S. Govt. Printing Office), 357-390.

Chase, T. E., Menard, H. W., and Mammerickx, I., 1971. Bathymetry of the North Pacific: La Jolla (Univ. of Calif.).

Cotillon, P., Ferry, S., Busnardo, R., et al., 1979. Synthèse stratigraphique et paléogéographique sur les faciès urgoniens du Sud de l'Ardèche et du Nord du Gard. Colloque sur l'Urgonien des pays méditerranéens (10-12 Sept. 1979, Grenoble), Geobios, 4:121-139.

Cotillon, P., Ferry, S., Gaillard, C., et al., in press. Fluctuations des paramètres du milieu marin dans le domaine vocontien (France $\mathrm{S}-\mathrm{E})$ au Crétacé inférieur: mise en evidence par l'étude des formations marno-calcaires alternantes. Bull. Soc. Géol. France.

Dean, W. E., Gardner, J. V., Jansa, L. F., et al., 1978. Cyclic sedimentation along the continental margin of northwest Africa. In Lancelot, Y., Seibold, E., et al., Init. Repts. DSDP, 41: Washington (U.S. Govt. Printing Office), 965-989.

Emiliani, C., 1978. The cause of ice ages. Earth Planet. Sci. Lett., $37: 349-352$.

Ferry, S., 1978. Les “calcaires à débris" barrémo-aptiens de la Drôme vocontienne (France S-E): des cônes d'épandage bioclastique en eau profonde. Doc. Lab. Géol. Fac. Sci. Lyon, 4:273-303. , 1979. Les turbidites bioclastiques: mode de transport du sable calcaire des plates-formes urgoniennes à la cuvette vocontienne (S-E de la France). Colloque sur l'Urgonien des pays méditerranéens (10-12 Sept. 1979, Grenoble), Geobios, 4:149-158.
Ferry, S., and Flandrin, J., 1979. Mégabrèches de resédimentation, lacunes mécaniques et pseudo-"hard grounds" sur la marge vocontienne au Barrémien et à l'Aptien inférieur. Géol. alpine, 55:75-92.

Hamilton, E. L., 1956. Sunken Islands of the Mid-Pacific Mountains. Geol. Soc. Am. Mem., 64.

Lancelot, Y., and Larson, R. L., 1975. Sedimentary and tectonic evolution of the northwestern Pacific. In Larson, R. L., Moberly, R., et al., Init. Repts. DSDP, 32: Washington (U.S. Govt. Printing Office), 925-939.

Manivit, H., 1979. Les nannofossiles. In Busnardo, R., Thieuloy, J. P., Moullade, M., et al. (Eds.), Hypostratotype mésogéen de l'étage Valanginien ( $S-E$ de la France): Paris (Ed. du CNRS), pp. $87-98$.

Masse, J. P., 1976. Lés calcaires urgoniens de Provence [These]. AixMarseille II, France.

Mathieu, M., 1965. Le Néocomien dans le Sud du Bassin Parisien. Colloque sur le Crétacé inférieur, Mem. Bur. Rech. Géol. Min., 34:587-604.

Middleton, G. V., and Hampton, M. A., 1976. Subaqueous sediment transport and deposition by sediment gravity flows. In Stanley, D. J., and Swift, W. J. P., (Eds.), Marine Sediment Transport and Environmental Management: New York (Wiley), pp. 197-218.

Mountjoy, E. W., Cook, H. E., Pray, L. C., et al., 1972. Allochthonous carbonate debris flows-worldwide indicators of reef complexes, banks and shelf margins. 24th Internat. Geol. Congress (Montreal, 1972), Sec. 6, pp. 172-189.

Nöel, D., 1968. Nature et genèse des alternances de marnes et de calcaires du Barrémien supérieur d'Angles (Fosse vocontienne, Basses-Alpes). C. R. Acad. Sci. Paris, 266:1223-1225.

d'Orbigny, A., 1850. Prodrome de paléontologie universelle des animaux Mollusques et Rayonnés: Paris (Masson).

Porthault, B., 1978. Géochimie et environment sédimentaire. Exemple d'application dans l'étude du Crétacé du bassin rhodanien. Doc. Lab. Géol. Fac. Sci. Lyon, 4:361-392.

Shackleton, N. J., and Opdyke, N. D., 1976. Oxygen-isotope and paleomagnetic stratigraphy of pacific core V28-239, late Pliocene to latest Pleistocene. Geol. Soc. Am. Mem., 145:449-464.

Shinn, E. A., 1969. Submarine lithification of Holocene carbonate sediments in the Persian Gulf. Sedimentology, 12:109-144.

Smith, A. G., and Briden, J. C., 1977. Mesozoic and Cenozoic Paleocontinental Maps: Cambridge (Cambridge Univ. Press).

Thiede, J., and van Andel, Tj. H., 1977. The paleoenvironment of anaerobic sediments in the late Mesozoic South Atlantic Ocean. Earth Planet. Sci. Lett., 33:301-309.

van Hinte, J. E., 1976. A Cretaceous time scale. Bull. Am. Assoc. Petrol. Geol., 60:498-516.

Winterer, E. L., Ewing, J. I., et al., 1973. Site 171. In Winterer, E. L., Ewing, J. I., et al., Init. Repts. DSDP, 17: Washington (U.S. Govt. Printing Office), 283-334.

Zemmels, I., and Cook, H. E., 1973. X-ray mineralogy of sediments from the Central Pacific Ocean. In Winterer, E. L., Ewing, J. I., et al., Init. Repts. DSDP, 17: Washington (U.S. Govt. Printing Office), 517-559. 

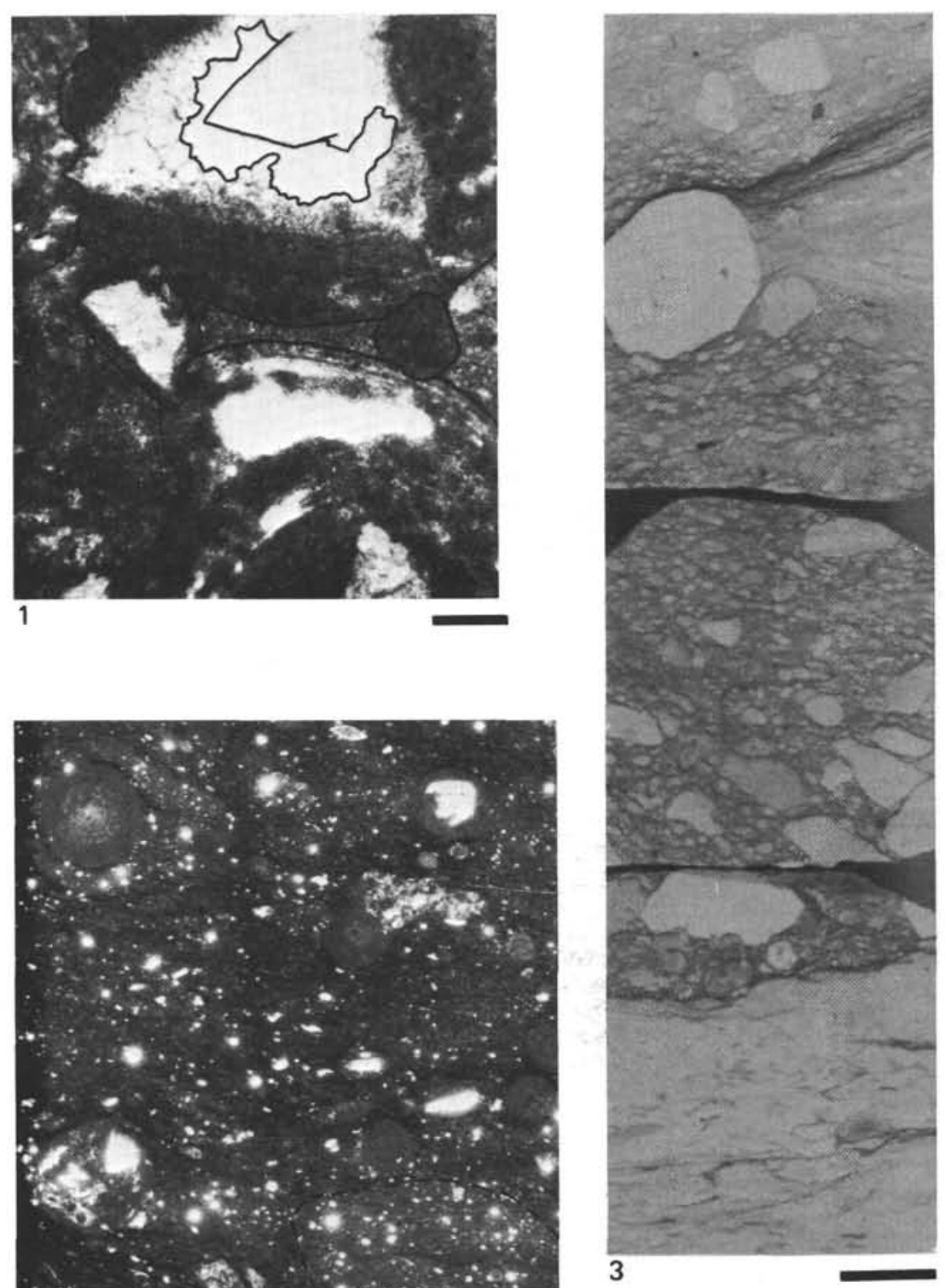

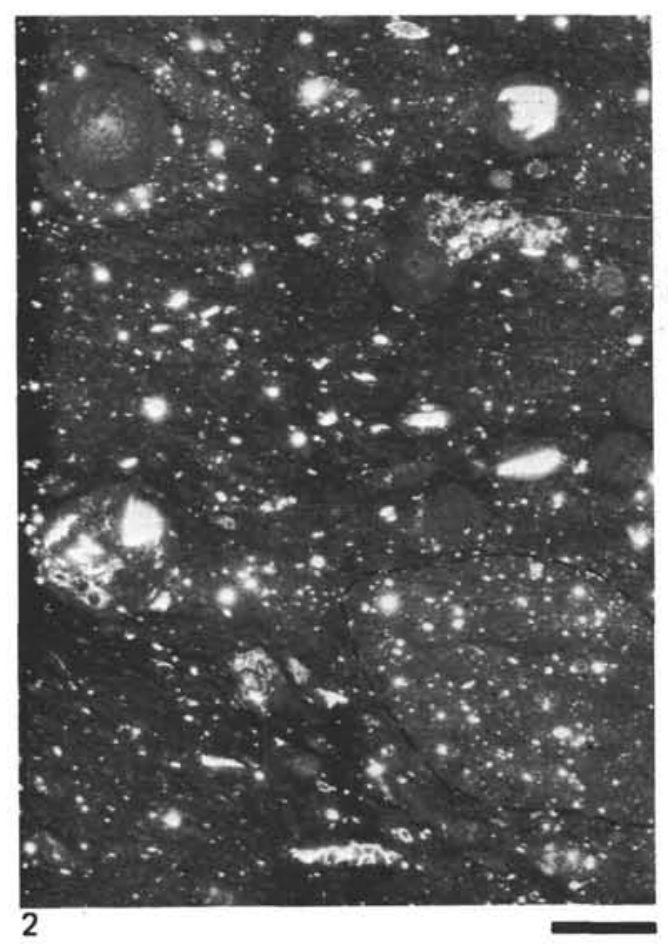

Plate 1. Gravity-reworked materials at Site 463.

Figure 1. Thin-section of coarse-grained, mainly oolitic packstone. Thick, graded layer with some "floating" pelagic clasts. Note pressure-welded grains (outlined), moldic porosity partly filled with drusy calcite (void outlined) in the above grain, and micritization in the oolite below. Voids in chalky micrite of the oolitic coating may have been produced during making of thin-section. 463-85-1, 133-135 cm. Scale bar represents $0.1 \mathrm{~mm}$.

Figure 2. Thin-section in a typical carbonate debris-flow deposit. Note the mixing of oolites and radiolarians (dissolved) in the

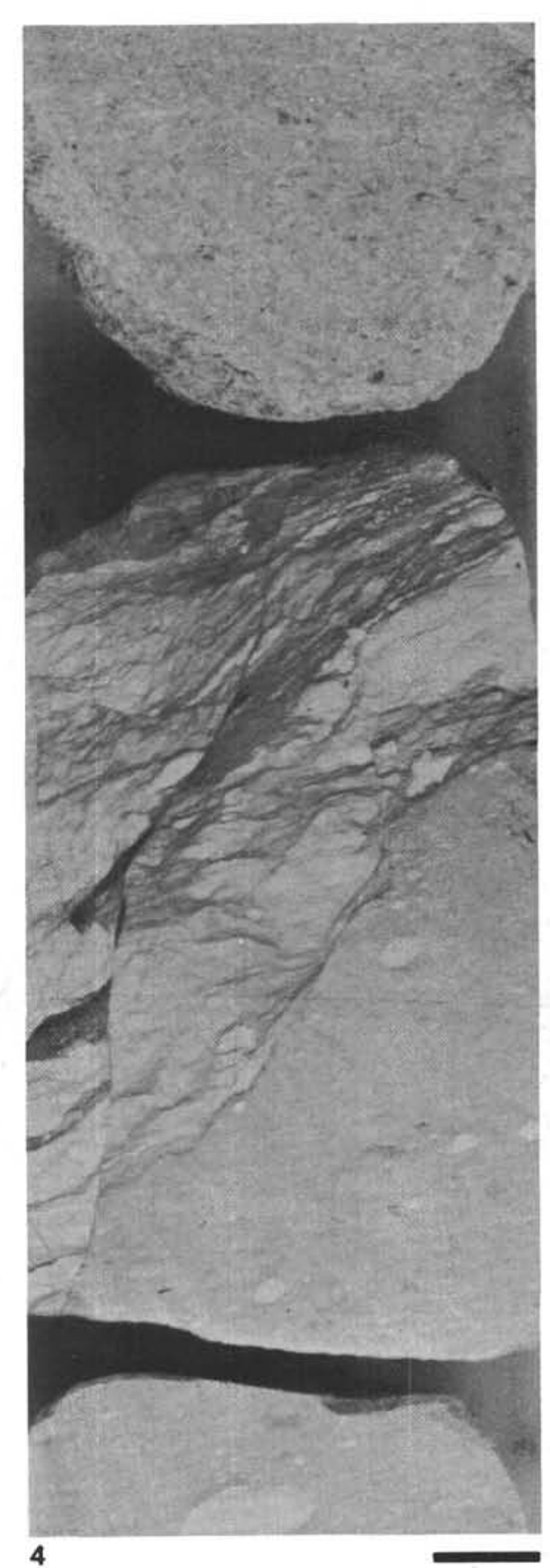

matrix, and the clast of radiolarian-rich pelagic limestone. 463-86-1, 49-51 cm. Barremian. Scale bar represents $1 \mathrm{~mm}$.

Figure 3. Lower part of a carbonate debris-flow deposit bearing numerous pelagic clasts (some pressure-welded), and resting on bioturbated pelagic limestone along a sharp, erosional contact. $463-85-2,22-35 \mathrm{~cm}$. Barremian. Scale bar represents $1 \mathrm{~cm}$.

Figure 4. Typical core, showing, at the base, the upper part of a debris-flow deposit, and, at the top, the very faintly laminated lower part of a graded turbidite bed; between them, slipped pelagic limestones which have been affected by post-depositional tensional microfaults. 463-86-1, 34-48 cm. Barremian. Scale bar represents $1 \mathrm{~cm}$. 


\section{S. FERRY, A. SCHAAF}
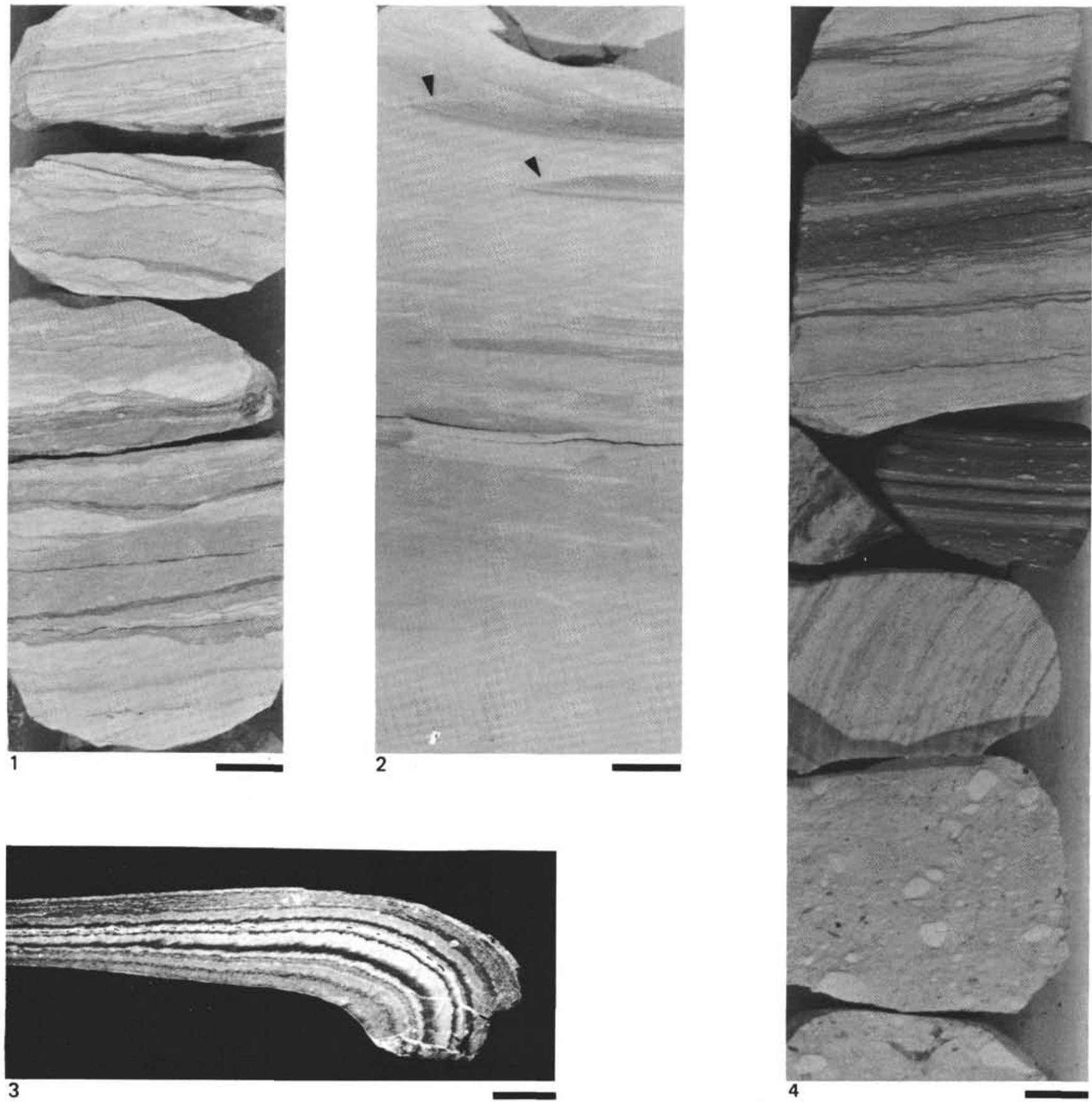

3

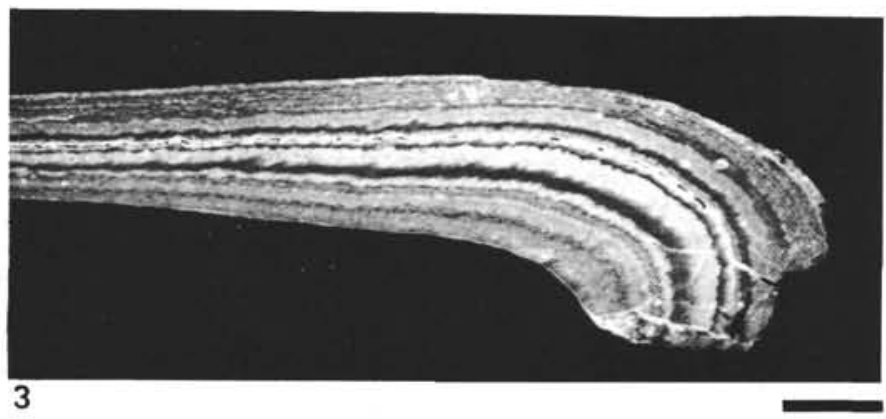

Plate 2. Gravity-reworked materials at Site 463. (On all photographs, bar scale represents $1 \mathrm{~cm}$.)

Figure 1. Irregular, wavy lamination in pelagic limestone, produced by shearing in slump folds. Such features are very common in folds of Vocontian slumps. 463-71-4, 50-62 cm. Lower Aptian.

Figure 2. Another kind of slippage feature (arrows), perhaps corresponding to the beginning of creep in very watery muds. 463-65-3, 16-32 cm. Upper Aptian.

Figure 3. Part of a slump fold from the Vocontian Trough, showing parallel lamination produced by shearing during slumping. Dark laminae are more-argillaceous than the white ones. This pseudobedding is produced by multiple folding and shearing during the slide of an alternation of pelagic limy beds and marly interbeds whose thicknesses range from between 5 to $10 \mathrm{~cm}$ (marls) and 40 to $90 \mathrm{~cm}$ (limestones). Barremian.

Figure 4. Another example of slump-induced laminations in pelagic material, here resting on a debris-flow bed. White millimetric clasts in dark laminae are skeletal debris and oolites, rolled along internal slippage planes. Such mixing may be due to slumping and intense shearing of previously deposited turbidite layers, sandwiched in pelagic muds. $463-85-2,21-38 \mathrm{~cm}$. Barremian. 

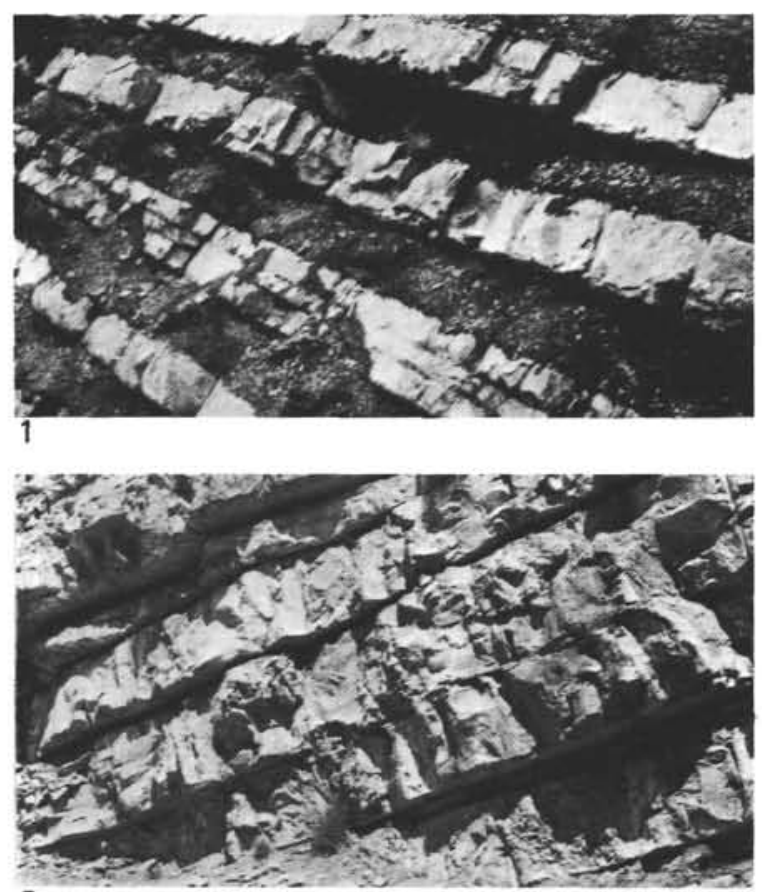

2
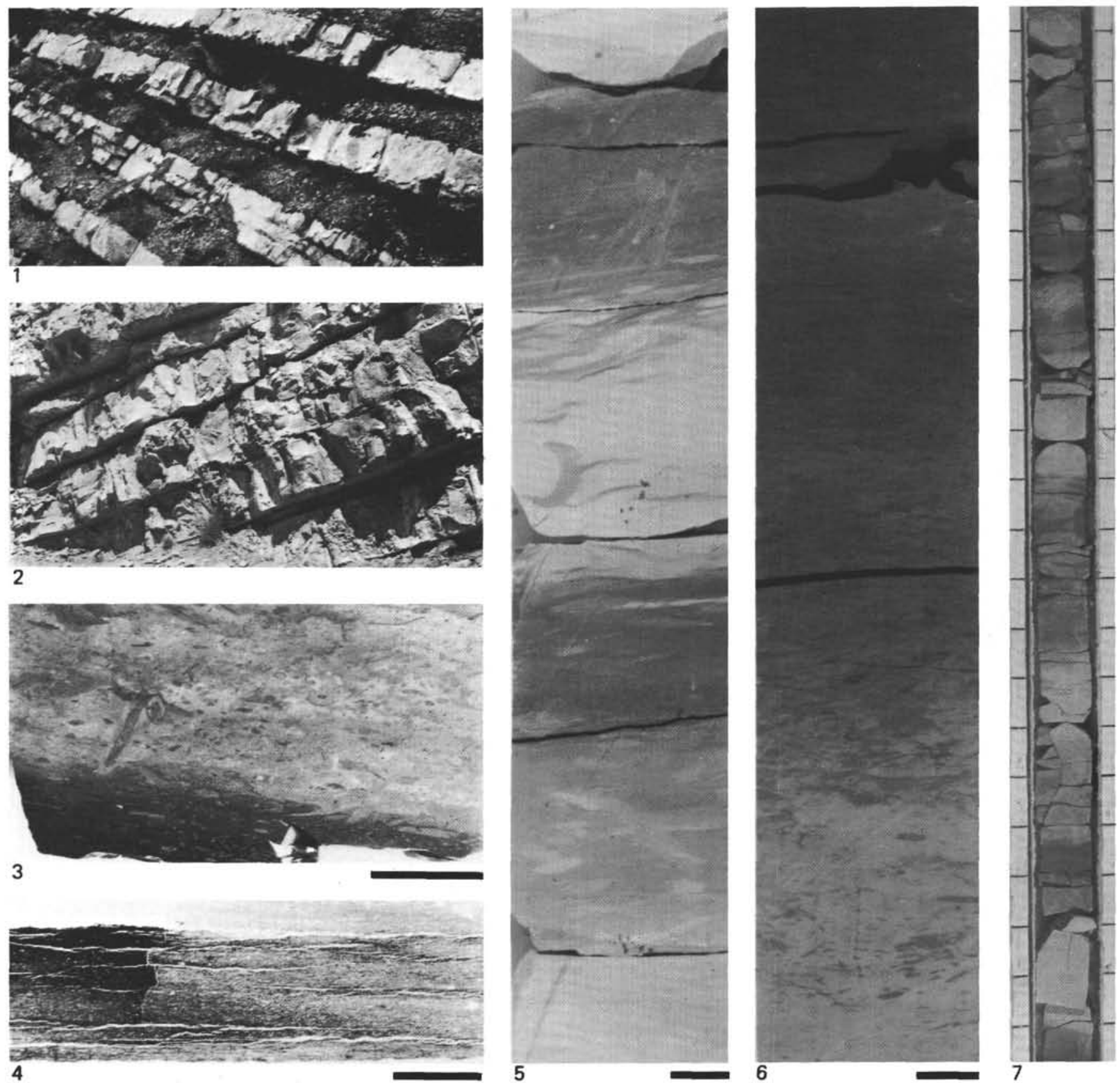
4

Figure 4. Marly layer with no bioturbation, indicating poor bottomlife conditions. Thin-section perpendicular to bedding. Upper Barremian. Scale bar represents $5 \mathrm{~mm}$. Sheet cracks are artifacts.

Figure 5. Very light-colored limestone beds alternating with pink-red or red, more-argillaceous or marly layers. $463-63-1,87-105 \mathrm{~cm}$. Upper Aptian. Scale bar represents $1 \mathrm{~cm}$.

Figure 6. Limestone-marl transition in gray-black sediments. Note the Chondrites-like bioturbation in limestone (below); upper part is black, laminated, and apparently not bioturbated. 463-70-1, 120-135 cm. Lower Aptian. Scale bar represents $1 \mathrm{~cm}$.

Figure 7. Typical core, showing well-recovered alternation (white: light-colored limestone beds; darker: red or pink-red, moreargillaceous layers), 463-73-4. Lower Aptian. Scale intervals $5 \mathrm{~cm}$ on both sides. 

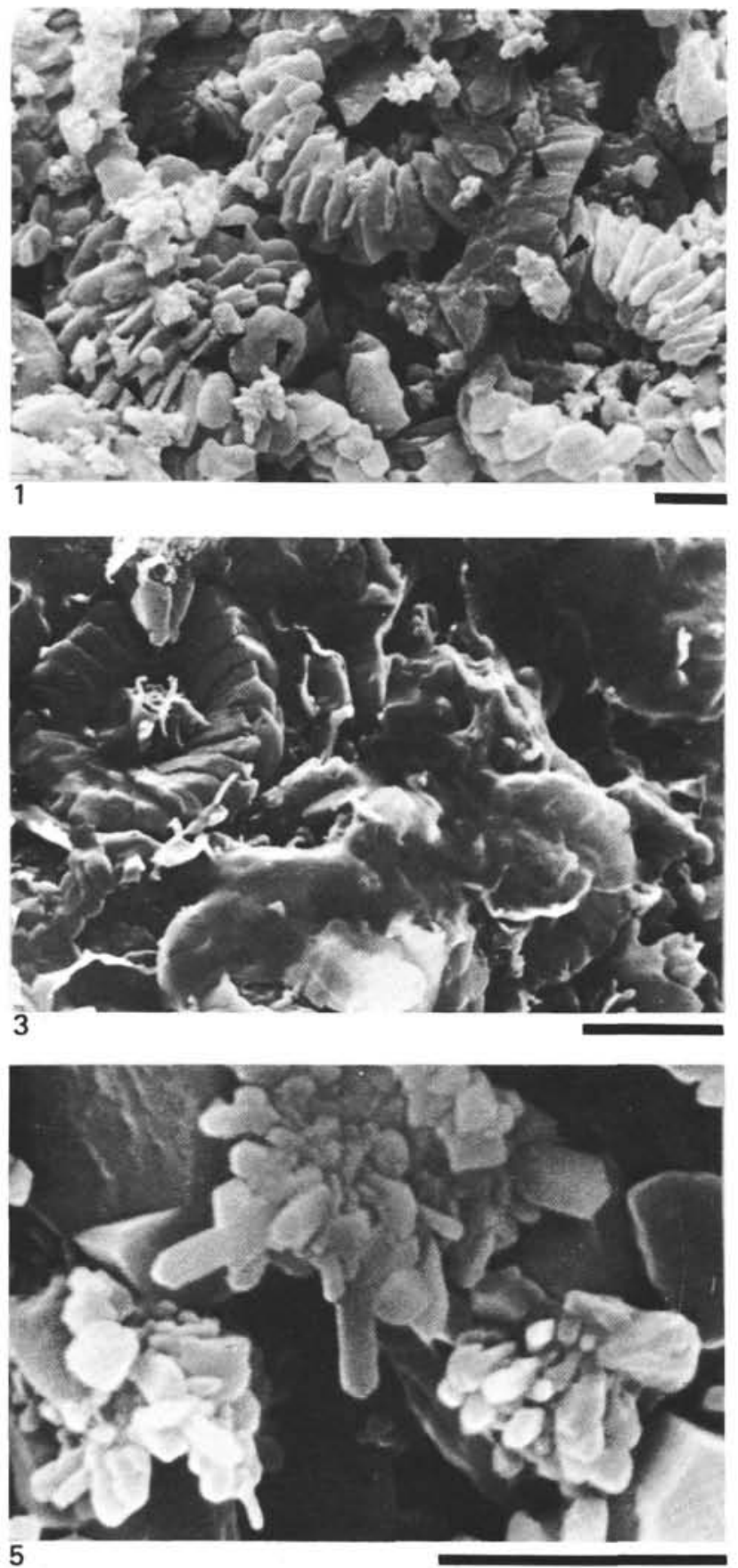

Plate 4. Nannofacies of pelagic limestone-marl alternations from the Pacific and the Tethys. (On all photographs, scale bar represents 2 $\mu \mathrm{m}$.

Figure 1. Slightly etched limestone from Site 463. Nannoconus always abundant among coccoliths. Note clusters of diagenetic quartz crystals (arrows) between nannofossils. 463-63-1, 106-108 cm. Upper Aptian.

Figure 2. Etched, slightly argillaceous pelagic limestone from the Vocontian Trough. Abundant Nannoconus. Clay aggregates between nannofossils also contain diagenetic quartz crystals (arrow). Upper Barremian.
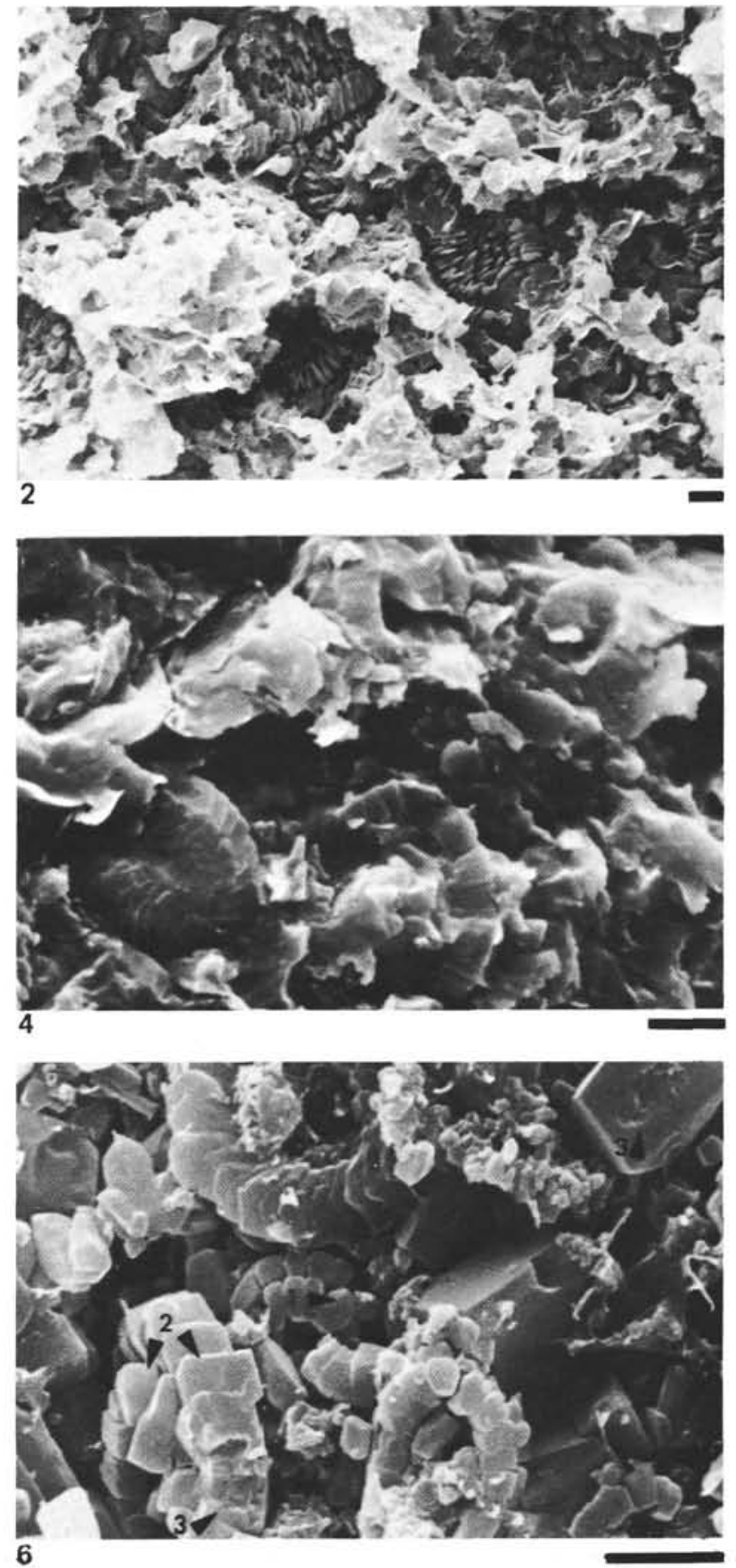

Figure 3. Red, marly interbed from Site 463 . Only coccoliths in the argillaceous matrix. 463-60-2, 124-126 cm. Uppermost Aptian.

Figure 4. Dark-gray, marly interbed from the Vocontian Trough. As in the Pacific, only coccoliths in the argillaceous part. Lower Barremian.

Figure 5. Enlargement of clusters of euhedral diagenetic quartz crystals which grew in the pore spaces between nannofossils in pelagic limestone. 463-85-2, 27-29 cm. Barremian.

Figure 6. Diagenesis in pelagic limestones from Site 463 . Note partly dissolved coccoliths (1), calcite overgrowths on others (2), and embayment of early quartz clusters in calcite overgrowths (3). 463-60-2, 106-108 cm. Uppermost Aptian. 